Review

\title{
Advances in cancer treatment: a new therapeutic target, Annexin A2
}

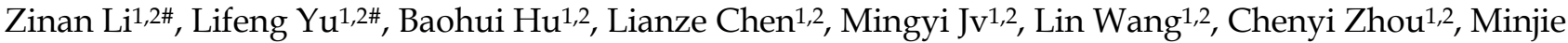 \\ Wei ${ }^{1,2,3 凶}$ and Lin Zhao ${ }^{1,2}$ \\ 1. Department of Pharmacology, School of Pharmacy, China Medical University, No.77 Puhe Road, Shenyang North New Area, Shenyang City, 110122 \\ Liaoning, China. \\ 2. Liaoning Engineering Technology Research Center, China Medical University, No.77 Puhe Road, Shenyang North New Area, Shenyang City, 110122 , \\ Liaoning, China. \\ 3. Liaoning Medical Diagnosis and Treatment Center, Liaoning Province, China.
}

\#These authors contributed equally to this work.

$\triangle$ Corresponding authors: Minjie Wei and Lin Zhao, PhD, Department of Pharmacology, School of Pharmacy, China Medical University, No.77 Puhe Road, Shenyang North New Area, Shenyang 110122, Liaoning, China. E-mail: weiminjiecmu@163.com; lzhao@cmu.edu.cn.

(c) The author(s). This is an open access article distributed under the terms of the Creative Commons Attribution License (https://creativecommons.org/licenses/by/4.0/). See http://ivyspring.com/terms for full terms and conditions.

Received: 2020.10.28; Accepted: 2021.02.25; Published: 2021.04.24

\begin{abstract}
Annexin A2 (ANXA2) is a calcium regulated phospholipid-binding protein. It is expressed in some tumor cells, endothelial cells, macrophages, and mononuclear cells, affecting cell survival and mediating interactions between intercellular and extracellular microenvironment. Aberrant expression of ANXA2 can be used as a potential predictive factor, diagnostic biomarker and therapeutic target in cancer therapy. Investigators used various technologies to target ANXA2 in a preclinical model of human cancers and demonstrated encouraging results. In this review article, we discuss the diagnosis and prognosis latent capacity of ANXA2 in progressive cancers, focus on the exploration of restorative interventions targeting ANXA2 in cancer treatment. Further, we comment on a promising candidate therapy that is conceivable for clinical translation.
\end{abstract}

Key words: Annexin A2, cancer, target, cancer therapy

\section{Introduction}

Annexin A2 (also called ANXA2, annexin II, p36), $39 \mathrm{kDa}$ proteins (appearing as a $36 \mathrm{kDa}$ protein by SDS-PAGE) from the calcium-dependent phospholipid-binding peripheral membrane proteins family [1], is characterized by the ability to bind and aggregate anionic phospholipid membranes [2]. This calcium-dependent binding and aggregating ability makes up the foundation of its biological functions including vesicular transport, exocytosis, and endocytosis. Otherwise, ANXA2 participate in cell survival, proliferation, invasion and metastasis, thus acts as a regulator in tumor growth and progression, which support that ANXA2 is a proposing target in cancer treatment [3]. The aberrant expression character of ANXA2 showed in a wide range of cancer cells turn it into emerging biomarker for cancers [4]. In this review, we summarize the characteristics and roles of ANXA2 and existing therapeutic strategies targeting ANXA2, and propose a prospective compound targeting ANXA2.

\section{Characteristics of Annexin A2}

There are two functional regions of ANXA2 underling its binding and aggregating activity: the $\mathrm{N}$-terminal domain and the C-terminal core domain. The N-terminal domain contains the tissue plasminogen activator (tPA)- [5] and S100A10 (also called p11)-binding site, it also bears multiple phosphorylation sites such as Tyr23 and Ser25, which can be phosphorylated by Src kinase and protein kinase $C[6,7]$. The phosphorylated ANXA2 changes its intracellular localization and regulating actions [8-12]. The core domain consists of four segments of internal and interannexin homology that are easily 
identified in a linear sequence alignment [13]. It constitutes a highly a-helical disk with two principal sides, the convex and the concave $[1,14]$. The convex surface underlies membrane-binding ability in a calcium-dependent manner. The concave surface, meanwhile, plays a key role in membrane bridging and has the ability to anchor the $\mathrm{C}$ terminus of the $\mathrm{N}$-terminal domain [15]. The core domain includes the F-actin- [16], heparin- [17] and plasminogen-binding sites [18]. It mediates the cycle of ANXA2 between cytosol and the cytosolic surface of cellular membranes through $\mathrm{Ca}^{2+}-$ regulated way [19]. The C-terminal core domain determines membranebinding capability of ANXA2 [20], while N-terminal domain underlies paralog-specific functions in ANXA2. It is pointed out that the N-terminal domain is necessary in targeting to endosomes in vivo [21]. Tyr-23 phosphorylation in the N-terminal promotes the membrane-surface ANXA2 binding to endosomes [10]. Reactive redox-sensitive cysteines residue (Cys-8) in the N-terminus can regulate cycles of oxidation and reduction [22]. Extracellular ANXA2 bind to enzyme plasmin and oxidized during this reaction, oxidation form of ANXA2 subsequently reduced by the thioredoxin redox system. Reduced form of ANXA2 can protect tumor proteins from oxidation. Which means ANXA2 plays a key role in resisting oxidative stress and in tumorigenesis [23]. Structural studies indicated that the flexibility of the $\mathrm{N}$-terminal domain and C-terminal core domain is interrelated and oppositely regulated by Ser25Glu phosphomimicking mutation and Tyr23 phosphorylation. Ser25Glu mutation disrupts the connection of N-terminal domain and C-terminal core domain, while Tyr23 phosphorylation anchors the $\mathrm{N}$-terminal domain to the C-terminal domain and inhibit the membrane-bridging function. This inhibition can be returned by S100A4 and S100A10 binding [24].

ANXA2 exists as monomeric and heterotetrameric (comprised of two ANXA2 and two S100A10 molecules) forms in cells. The monomer exists in the cell cytoplasm, nuclei and on early endosomes while the heterotetramer located on cell membranes [25]. Nuclear ANXA2 can be the component of the primer recognition proteins regulating DNA polymerase a activity and DNA replication [26, 27]. Nuclear ANXA2 is also a major nuclear DNA-binding protein and be associated with DNA synthesis, cell proliferation and cell cycle progression [28, 29]. Otherwise, accumulation of ANXA2 in nuclear protects cells from DNA damage during oxidative stress [30]. ANXA2 binds to specific mRNAs in cytoskeleton and perinuclear section. ANXA2 in the cytoplasm and on the surface of membranes can serve as mediators in membrane-related processes, including exocytosis [31, 32], endocytosis [25, 33], and membrane trafficking [34]. A founding proved that ANXA2 involved in biogenesis of polycystic transport intermediates via regulating the budding process of early endosomes rather than membrane invagination [35]. N-terminal domain, especially tyr-23 phosphorylation in the $\mathrm{N}$-terminal, is necessary in this process $[10,21]$. The heterotetramer on the cell surface is regulated by intracellular calcium concentration. Change of intracellular calcium concentration can be provoked by heat induced stress of the cell. When using the small interfering RNAs (siRNA) which can specifically bind to S100A10 and subsequently reduce its expression, translocation of ANXA2 triggered by the heat was therefore significantly reduced. S100A10 plays an essential role in ANXA2 translocation [12]. Calcium-dependent constructional change of ANXA2 exposes a hydrophobic amino acid, it combined with S100A10 and form the heterotetramer. The high affinity for phospholipids drives heterotetramer translocate from the cytoplasm to the extracellular plasma membrane $[12,36]$. The heterotetramer is a key plasminogen (PLG) receptor that transforms PLG into plasmin [37]. Plasmin is an important regulator of ECM degradation, fibrin polymers lysis and furthermore migration, invasion and angiogenesis [38].

\section{Roles of Annexin A2 in cancer progression}

ANXA2 perform crucial roles in tumor cancer progression [3, 4, 39-45]. For tumor development, promoting cell proliferation and inhibiting cell apoptosis are both required for survival and growth. Neoangiogenesis, meanwhile, is another fundamental biological process in tumor progression [46]. It is well known that nutrition and oxygen are indispensable for tumor cells to survival and growth. So, in the early stage of tumor starvation, ANXA2 may support starving cells by inducing autophagy [47]. Invasion and metastasis of tumor cells improve the aggressive potential of human cancer. Increased researchers have focused on roles of ANXA2 on proliferation, migration, invasion and metastasis of tumor cells. (Figure 1).

\section{Roles of Annexin A2 in cell proliferation}

In nuclei, ANXA2 monomer combined with 3-phosphoglycerate kinase (PGK). This complex stimulates DNA polymerase alpha in the early $\mathrm{S}$ phase and initiates the DNA replication [27]. In addition, nuclear ANXA2 disrupts coilin and causes its abnormally localized to centromeres, resulting in chromosome instability (CIN). CIN is a promotor of 
tumor growth [48-50]. Study showed that cancer cells transfected with an antisense ANXA2 vector show poor capability of division and proliferation. Cellular DNA synthesis level in antisense transfected cells is significantly lower than that in sense transfected cells. Meanwhile, replication extracts made from antisense transfected cells have significantly reduced efficiency to support SV40 in vitro DNA replication, while those made from sense transfected cells have fully capability of replication [51]. Down-regulation of ANXA2 lead to reduction of the percentage of cells in the $S$ phase [52]. The results agree with that ANXA2 can promote cell proliferation by regulating DNA synthesis, replication and the cell cycles. Researchers also point out that ANXA2 activate both NF-kB and $\beta$-catenin signaling pathways thus causing cell proliferation in vivo [53].

\section{Roles of Annexin A2 in cell apoptosis}

Inhibiting cell apoptosis are essential factor in tumor survival and proliferation. ANXA2 is significant ligand of $\mathrm{Clq}$ which directly binding to apoptotic cells and mediating phagocytes recognizing apoptosis cells [54, 55]. P53 serves as a key tumor suppressor protein by preventing cellular transformation [56]. The level of p53 impacts its target gene expression and regulates cellular functions such as cell cycle and apoptosis [57]. ANXA2 influences p53 level by activating JNK/c-Jun signaling, thus suppress expression of $\mathrm{p} 53$ and its downstream genes, p21, GADD45 and BAX, which play roles in promoting apoptosis [58, 59]. An experiment analysis the ANXA2 level of cells infected by p53 gene, it turns out that reduced expression was detected in all cell lines infected by Adv-p53 (a reconstructed adenovirus encoding wild type p53 gene) [60]. In NSCLC cell lines, silencing ANXA2 led to up-regulation of p53 expression and inhibits cell proliferation [61]. Knockdown of ANXA2 up-regulating the level of p53 and its downstream gene [62]. In addition, it is also reported that knockdown of ANXA2 promoting the lung cancer cell apoptosis [63]. Accumulating data suggest that ANXA2 participates in cellular apoptosis via regulating the expression level of p53.

\section{Roles of Annexin A2 in cell invasion and metastasis}

Studies showed that down-regulating of ANXA2 inhibiting tumor cell invasion and metastasis, and overexpression of ANXA2, promote the invasion and metastasis capability of tumor cells [52, 64-69]. Anti-ANXA2 antibody have been proved to serve as a suppressor in tumor invasion and metastases [59, 70-75]. The ANXA2 heterotetramer specifically binding tPA on the surface of cell membrane and transform plasminogen (PLG) into plasmin that contribute to extracellular matrix (ECM) degradation and fibrin polymers lysis [76]. Plasmin initiates neoangiogenesis and support tumor cell getting nutrition and oxygen [77, 78]. Degradation of ECM and lysis of fibrin polymers provide space for migration. Membrane synthesis and cytoskeletal

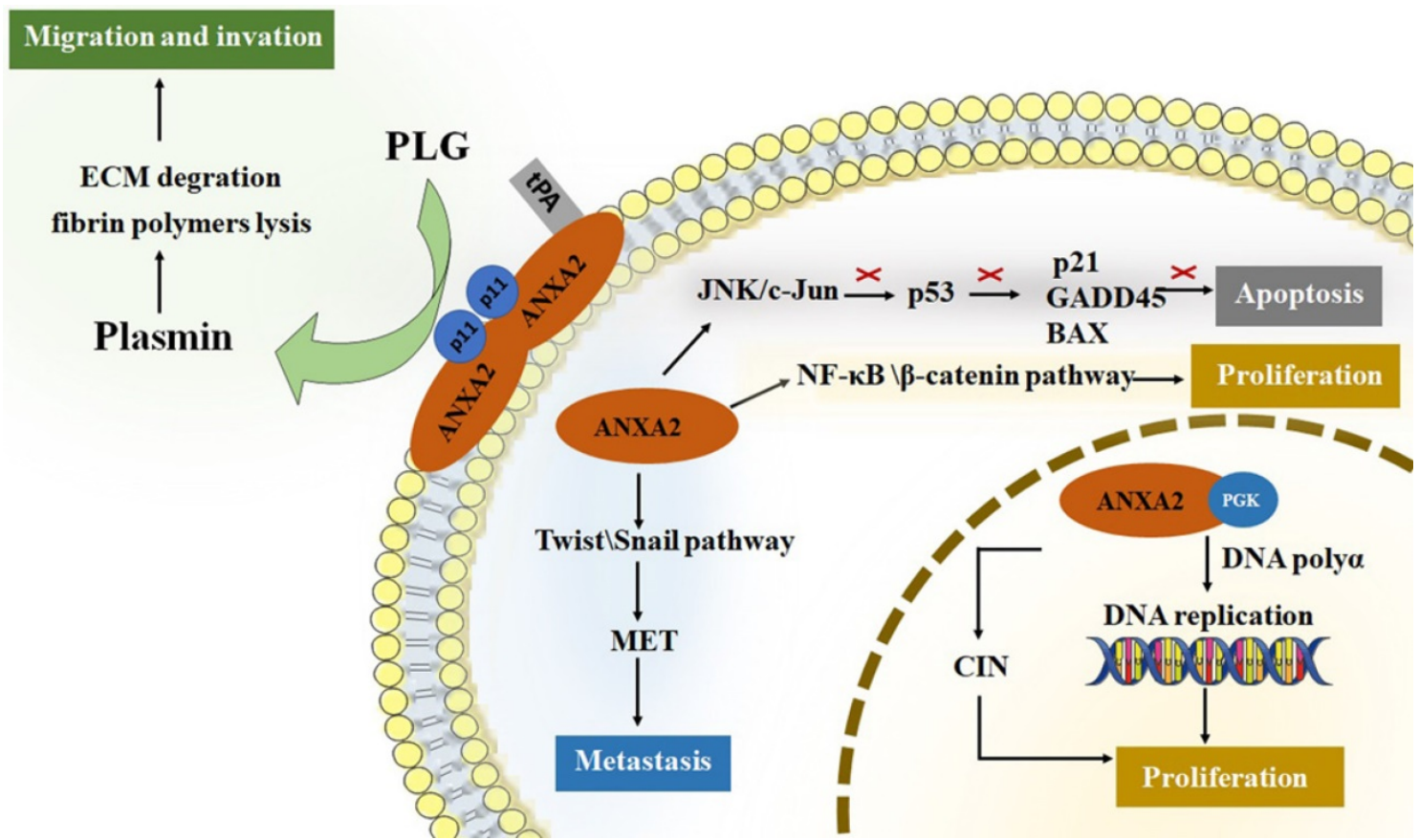

Figure 1. The roles of ANXA2 in cell development. ANXA2 represents essential promoter in cell proliferation, migration, invasion and metastasis, concurrently inhibit the apoptosis. tPA, tissue plasminogen activator; PGK, phosphoglycerate kinase; CIN, chromosome instability; PLG, plasminogen; ECM, extracellular matrix; EMT, epithelialmesenchymal transition. 
rearrangements, meanwhile, are key factors in process of migration. ANXA2 has the ability to bind polymerized and monomeric actin and maintain the plasticity of the dynamic membrane-associated actin cytoskeleton [79]. In addition, epithelial-mesenchymal transition (EMT) is an essential process of metastasis in cancers. It provides stationary epithelial cells a chance to lose junctions with each other and be capable to migrate and invade [80-82]. Downregulation of ANXA2 block cell proliferation and invasion accompanied by reduction of $\beta$-catenin and inhibition of EMT. While over expression of $\beta$-catenin reversed the negative effect on EMT [72]. Transforming growth factor $\beta$ (TGF- $\beta$ ) is an EMT inductor. TGF- $\beta$ upregulates ANXA2 and activates internalization of both E-cadherin and ANXA2. ANXA2 overexpression promotes cell invasiveness through Src/ANXA2/STAT3 pathway. Silencing ANXA2 prevented TGF- $\beta$-induced invasion. Inhibition of Src/ANXA2/STAT3 pathway reversed the EMT process [83]. Twist and Snail are recognized as key factors in EMT initiation. They decrease epithelial proteins (i.e., E-cadherin) and increase mesenchymal proteins (i.e., N-cadherin, fibronectin, $\beta$-catenin, and vimentin), providing a chance for cancer cells to escape from one organ to a different indirectly connected one [81]. Study on level of twist and snail in NPC cells proved this mechanism [84]. The level of twist and snail decreased in ANXA2-knockdown NPC cells, and those cells maintain the endothelial-like phenotype rather than a mesenchymal-like phenotype.

\section{Annexin A2 is an emerging biomarker for cancers}

\section{Overexpression of Annexin A2 in cancer cell}

Aberrant expression of ANXA2 is observed in extensive range of cancer cells. In breast cancer cell, expression of ANXA2 is detected in the metastatic MDA-MB231 cell but not in the nonmetastatic MCF-7 cell $[85,86]$. Overexpression of ANXA2 detected both in herceptin resistant and Her-2 negative breast cancer cells [87]. In 105 cases of primary colorectal carcinoma tissues, ANXA2 is overexpressed in the cancer cell membrane of the carcinoma cells more than in tumor stroma fibrous tissue, the muscularis propria, the vessel wall, and the adjacent normal bowel wall. Similar results also showed in other colorectal cancers $[88,89]$. A clinical data collected 150 pairs of colorectal carcinoma tissue and the corresponding paracancerous tissue shows that ANXA2 is overexpressed in tumor cells and mainly located in the plasma membrane [90]. A study based on immunohistochemistry provide evidence of
ANXA2 presence in cancer samples, ANXA2 expression was increased in human tumor tissues. And ANXA2 levels were higher in stage IV and metastasis tumors compared with stage I-III. While E-cadherin, an epithelial marker, decreased in stage II-IV and increased in metastasis [83]. Moreover, the expression of ANXA2 is positively correlated with histological type, tumor size, depth of invasion, and pathological tumor-node-metastasis stage. Higher level of ANXA2 is detected in human colorectal carcinoma cell lines including SW480, SW620, HCT116 and HT29 than normal colonic epithelial cell line NCM460 [69]. In 153 primary gastric carcinoma patients, about $30 \%$ are immunopositive for ANXA2 [90]. In another 436 gastric cancer cases, 133 gastric cancer tissue display upregulation of ANXA2. Additionally, ANXA2 expressed more strongly in the cell membrane than that in the cytoplasm of carcinoma cells [91]. In terms of hepatocellular carcinoma (HCC), both the expression level and tyrosine phosphorylation of ANXA2 are upregulated in HCC compared to normal or cirrhosis tissue [92]. Intense ANXA2 immunoreactivity is detected in lung adenocarcinoma, squamous cell carcinoma and non-small cell lung cancer (NSCLC) [59, 63, 93, 94]. Additionally, increased expression of ANXA2 detected in acute promyelocytic leukemia (APL) [95-97], glioma [98], multiple myeloma (MM) [99], pancreatic cancer [100-102] and oral squamous cell carcinoma (OSCC) [103, 104]. To further confirm expression of Annexin A2 gene in cancers, we performed bioinformatics analysis to detect Annexin A2 gene level in different cancer cells (Figure 2). ANXA2 overexpressed in colon adenocarcinoma (COAD), rectum adenocarcinoma (READ), liver hepatocellular carcinoma (LIHC), pancreatic adenocarcinoma (PAAD), stomach adenocarcinoma (STAD). The results are in accordance with abovementioned studies. This analysis also indicates high expression of ANXA2 in cervical and endocervical cancers (CESC), lymphoid Neoplasm Diffuse Large B-cell Lymphoma (DLBC), glioblastoma multiforme (GBM), kidney renal papillary cell carcinoma (KIRP), brain lower grade glioma (LGG), ovarian serous cystadenocarcinoma (OV), testicular germ cell tumors (TGCT), thymoma (THYM).

\section{Prognostic and diagnostic significance of Annexin A2 in cancers}

Detection of ANXA2 level is of interest due to its prognostic and diagnostic significance in cancer treatment. It is pointed out that ANXA2 overexpression in NSCLC [59], HCC [105], serous ovarian cancer [106], biopsies of epithelial ovarian cancer [107], urothelial carcinoma [108], breast cancer 
$[109,110]$ and nasopharyngeal carcinoma (NPC) [84] was associated with poor prognosis. A meta-analysis performed on 2321 patients with various cancers to confirm that high expression of ANXA2 was correlated with both overall survival (OS) (hazard ratio [HR] 1.56; $\mathrm{p}<0.001)$ and disease-free survival (DFS) (HR 1.47; $\mathrm{p}<0.001$ ) [111]. On the other hand, ANXA2 performs the function of a diagnostic factor for screening cancers. Increased ANXA2 serum level in peripheral blood has been evaluated in HCC [105, 112-114], gastric cancer [115] and OSCC [116]. The data are described in Table 1. Besides excessive ANXA2 can be detected in sera of cancer patients, it is also reported that high ANXA2 expression is related to a high risk of metastases and recurrence [84, 117]. It suggests that ANXA2 may represent a latent target of diagnosis and an emerging biomarker of prognosis in cancer therapy. Investigators have screened out a panel of probes, Tz6/10, and demonstrated those probes play the roles of cancer diagnosis and therapy by labeling and/or imaging ANXA2 from different cancer cell lines [118].

\section{Annexin A2 is a potential therapeutic target for cancers}

It is known that ANXA2 expression is upregulated in board spectrum of cancer cells. ANXA2 perform important roles in tumor progression, including cell survival, proliferation, migration, invasion and metastatic. In addition, abnormal expression of ANXA2 is link to multidrug resistance in cancer treatment [41, 66, 93, 119-121]. More attention has been focused on exploring therapies targeting ANXA2 in cancer treatment.

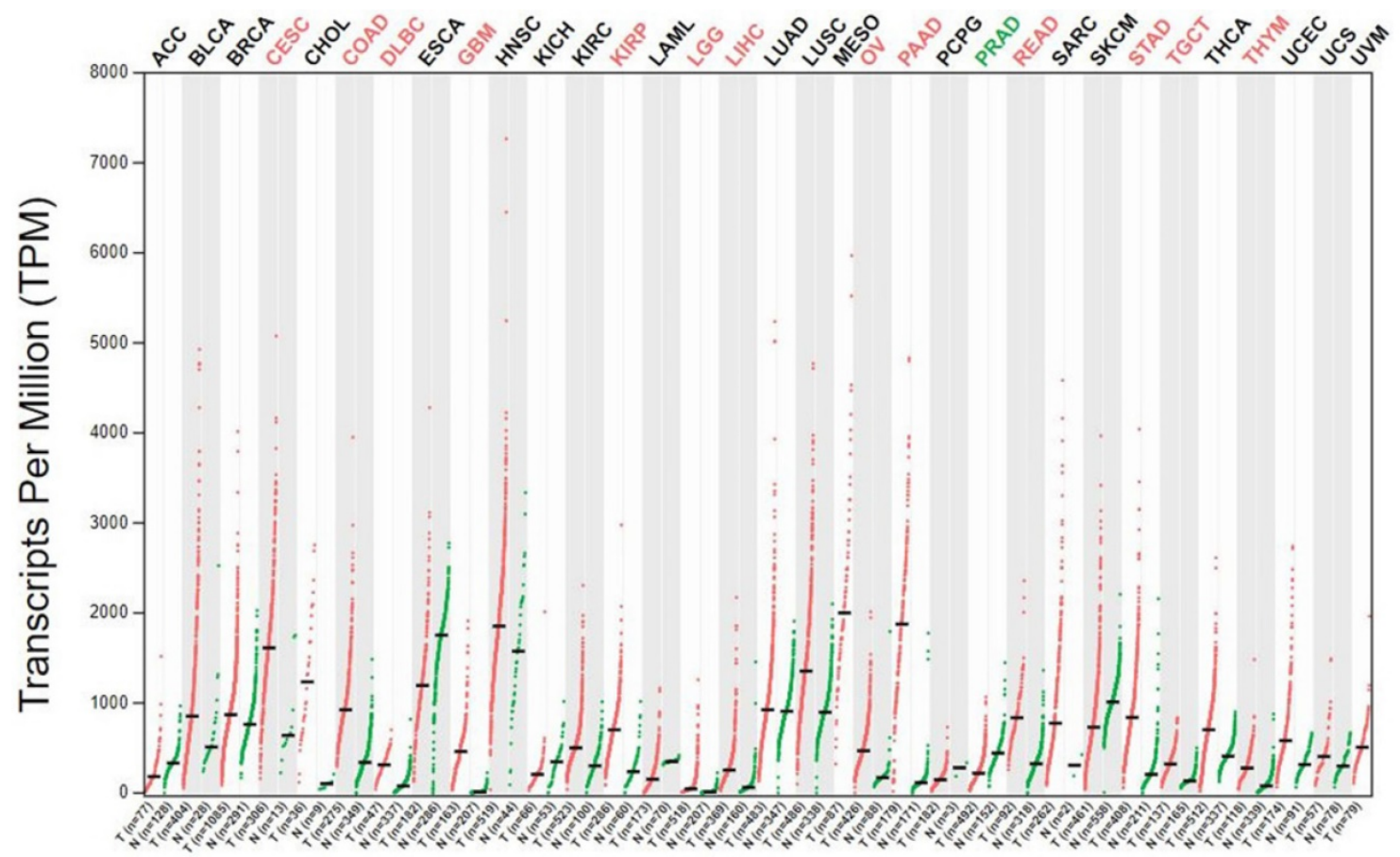

Figure 2. The expression of the ANXA2 gene in GEPIA database. ANXA2 is aberrantly expressed in a board range of cancer cells. The results consistent with the aforementioned studies.

Table 1. ANXA2 serum level in peripheral blood

\begin{tabular}{|c|c|c|}
\hline Cancer & Expression of ANXA2 & References \\
\hline $\mathrm{HCC}$ & $\begin{array}{l}\text { ANXA2 in peripheral blood significantly increased in HCC patients (median, } 69.6 \mathrm{ng} / \mathrm{ml} \text { ) compared to chronic liver disease } \\
\text { patients (median, } 16.8 \mathrm{ng} / \mathrm{ml} \text { ) and control group (median, } 9.5 \mathrm{ng} / \mathrm{ml})(\mathrm{p}<0.001)\end{array}$ & $\begin{array}{l}\text { Nevine El-Abd et } \\
\text { al }\end{array}$ \\
\hline $\mathrm{HCC}$ & $\begin{array}{l}\text { Significantly increased ANXA2 is detected in the sera of HCC (median, } 24.75 \mathrm{ng} / \mu \mathrm{l}) \text { compared with that in the healthy (median, } \\
16.69 \mathrm{ng} / \mu \mathrm{l}) \text {, benign tumor (median, } 19.92 \mathrm{ng} / \mu \mathrm{l}) \text {, hepatitis (median, } 6.48 \mathrm{ng} / \mu \mathrm{l}) \text {, and cirrhosis controls }(\text { median, } 7.39 \mathrm{ng} / \mu \mathrm{l})\end{array}$ & Sun et al \\
\hline $\mathrm{HCC}$ & $\begin{array}{l}\text { Higher expression }(\mathrm{t}=10.32, \mathrm{P}<0.001) \text { was found in the HCC group }(24.82 \pm 8.18 \mathrm{ng} / \mathrm{mL}) \text { than those in the benign liver disease } \\
\text { group }(12.80 \pm 7.21 \mathrm{ng} / \mathrm{mL})\end{array}$ & $\begin{array}{l}\text { Haijian Zhang et } \\
\text { al }\end{array}$ \\
\hline $\begin{array}{l}\text { Early stage } \\
\text { HCC }\end{array}$ & $\begin{array}{l}\text { Serum ANXA2 level is } 130 \mathrm{ng} / \mathrm{ml} \text { compared with } 15 \mathrm{ng} / \mathrm{ml} \text { and } 17 \mathrm{ng} / \mathrm{ml} \text { in chronic liver disease patients and control group } \\
\text { respectively }\end{array}$ & $\begin{array}{l}\text { Mohamed K } \\
\text { Shaker et al }\end{array}$ \\
\hline $\begin{array}{l}\text { Gastric } \\
\text { cancer }\end{array}$ & $\begin{array}{l}\text { ANXA2 levels in serum were significantly different between gastric cancer patients and control group (median, } 211.0 \text { vs. } 120.5 \\
\mu \mathrm{g} / \mathrm{mL} \text {, respectively }\end{array}$ & Faruk Tas et al \\
\hline OSCC & $\begin{array}{l}\text { The ANXA2 level was significantly higher in OSCC patients (median, } 27.1 \pm 9.81 \mathrm{ng} / \mathrm{mL} \text { ) than in patients with benign disease } \\
\text { and controls (median, } 15.9 \mathrm{ng} / \mathrm{mL} \text { and } 15.0 \mathrm{ng} / \mathrm{mL} \text {, respectively) }\end{array}$ & Wei Zhang et al \\
\hline
\end{tabular}

† HCC, hepatocellular carcinoma; ‡ OSCC, oral squamous cell carcinoma. 
ANXA2 was identified a bleomycin binding site in the pulmonary fibrosis which result in resistance for bleomycin treatment [121]. In the research, it is further proved that Glu139 (E139) of ANXA2 (ANXA2 ${ }^{\mathrm{E} 139 \mathrm{~A}}$ ) is required in bleomycin reduced pulmonary fibrosis. Mutating ANXA2 $2^{\mathrm{E} 139 \mathrm{~A}}$ in lung epithelial cells blocks the binding of bleomycin and ANXA2 and activates the transcription factor EB (TFEB) which regulates autophagy. TFEB-mediated autophagy substantially accelerates autophagic flux, leading to inhibition of epithelial cells apoptosis and proliferation, and ameliorates pulmonary fibrosis in bleomycin-treated mice. This founding makes ANXA2 a specific bleomycin target. Inhibiting ANXA2 may promote efficacy of bleomycin for cancer treatment.

Natural compounds are prospective directions in ANXA2-targeting therapy. Ginsenosides $\operatorname{Rg} 5$ and Rk1, having similar structure, have been found specifically binding to ANXA2. The interaction between those two ginsenosides and ANXA2 inhibit NF-kB activity and down-regulate inhibitor of apoptosis proteins, activating caspase and promoting apoptosis [122]. Investigators purified plant lectin from chickpea (cicer arietinum agglutinin) and testified the anti-tumor efficacy. It turns out that the plant lectin can inhibit tumor cell proliferation, migration and promote apoptosis by block the binding of ANXA2 and galectin-3, causing suppression of EGFR-mediated signaling [123]. Matrine, a plant alkaloid, purified from Chinese medical herb Sophora flavescens has been identified the anti-tumor activities by directly targeting ANXA2 [124].

Investigators have designed and constructed a chemical modified DNA/RNA hybrid nanoparticle for ovarian cancer. This nanoparticle consists of a thiodeoxyribonucleic acid aptamer targeting ANXA2 and a highly thermodynamically stable three way junction $(3 \mathrm{WJ})$ core motif derived from pRNA of phi29 bacteriophage. The other arm of pRNA-3WJ is extended with GC rich sequences for doxorubicin loading. This construction maintains the property of targeting ANXA2 and the cell toxicity of doxorubicin. In vivo experiment, nanoparticles remained integrated construction and are selectively enriched in tumors while little accumulation in healthy organs $6 \mathrm{~h}$ post-injection [125]. This result indicated that the novel cancer cell targeted drug delivery system may be a potential candidate to enhancing chemical drug efficiency in ovarian cancer treatment in an ANXA2-targeted manner. Another aptamer, ACE4G, is also demonstrated that it not only identifies ANXA2 on the membrane but realizes the enriched internalization into MCF-7 cell line [126].
It is reported that a cationic lipid-guided carrier with ANXA2 shRNA was designed to retarded tumor growth by silencing ANXA2, which have been proved a stable nanoparticle sustained targeting and localization in lung tumors nanoparticles both in vitro and in vivo [127].

Recently attentions have been focused on roles of microRNAs (miRNAs) in tumor regulations. MiR-206 has been testified directly targeting oncogenes KRAS and ANXA2 on tumor cell surface [128]. Further study revealed that ANXA2 N-terminus, especially Tyr23, play crucial roles in maintaining the high malignancy of colonic adenocarcinoma and miR-206 act as a tumor suppressor in colonic adenocarcinoma [129]. MiR-101 is also discovered being an ANXA2-targeted molecule and have capability of down-regulating expression of ANXA2 in drug-resistant gastric cancer [120].

Kim VM and his colleagues developed a Listeriabased, ANXA2-targeting cancer immunotherapy (LmANXA2) and testing its efficacy for PDAC within two murine models. It turns out that PDAC model mouse treated with Lm-ANXA2 showed high survival rate, supporting the assumption that Lm-ANXA2 can serve as a targeted agent for PDAC treatment [130].

An anti-ANXA2 monoclonal antibody (mAb) [67] generated in lab showed significant suppression of cell growth of breast tumor in vivo [131]. Simeon Cua and his colleagues generate a mAb, IgG1 2448, targeting a unique glycan epitope on ANXA2. It demonstrated good anti-tumor efficacy in vivo and indicated that 2448 can be a potential candidate of targeted therapy for ovarian and breast cancer [132, 133].

\section{A promising therapeutic strategy targeting Annexin A2}

Therapeutic strategy targeting ANXA2 have showed significantly antitumor effect both in vitro and in vivo in preclinical study, barely any of those reach clinical trials, especially the anti-ANXA2. The probable reason is that surface epitopes on ANXA2 are challenging to recapitulate for generation purposes [132]. In this review, we propose a prospective candidate for ANXA2-targeted therapeutic strategies, a targeting peptide selected via phage display technology showing highly selectivity and affinity to ANXA2.

There is a new peptide motif have been reported before [134], investigators discussed the LGRFYAASG peptide which is screened from internalizing phage peptide library in sarcoma cells. The peptide fused with the cell-penetrating peptide, pen motif, showed specific affinity and inhibitor effect in tumor cell. Notably, we get an ANXA2-targetting peptide motif - 
CBP12 (colorectal cancer binding peptide) in laboratory as well. We screened the phage display peptide libraries in human colorectal adenocarcinoma cell SW620 and human normal intestinal epithelial cell line HIEC (SW620 was used as the target cell and HIEC as the negative adsorption cell), collected the eluate and amplified by E. coli ER2738E infection. The CBP12 motif was specifically enriched after four rounds of selections. Consistently, we verified that phage display peptide CBP12 have specifically affinity to colorectal cancer cells. CBP12 can be a new targeting peptide and provide new directions in the early diagnosis and targeted therapies. Related articles will be published later.

Large number of literatures demonstrated the modification method of targeting peptide which inspire us the methods to improve the therapeutic effect of targeting peptide in tumor treatment. One way is to combine targeting peptide with classical killer peptide, KLA (KLAKLAKKLAKLAK), this kind of polypeptide showed favorable tumor cell toxicity and reduction of tumor volume in vivo with no apparent toxicities [135-137]. KLA is a proptosis peptide, contributing to cell death via causing mitochondrial swelling and permeabilization and the release of cytochrome $\mathrm{c}$, which disrupt mitochondrial membrane [138-142]. While KLA barely permeate the eukaryotic plasma membrane separately because of its characteristic of cationic amphipathic [143]. Accordingly, on the one hand, KLA requires the assistance of targeting peptides to transmembrane and play a role in programmed cell death. On the other hand, KLA shows no toxicity for normal cell as its low penetration in mammalian cells [144]. Alternatively, the concept of antibody-drug conjugate (ADC) proposes different direction in cytotoxic payload link to the specific antibody [145-148]. We can link the targeting peptide with the cytotoxic compounds which have been announced anti-tumor efficacy in clinical. Those compounds including auristatins, derivatives of dolastatin 10 [149]; maytansine, a potent microtubule inhibitor [150]; calicheamicin, a DNA damaging agent causing DNA double strand breaks [151]; duocarmycin and indolinobenzodiazepine pseudodimers, DNA damaging agents alkylating DNA [152, 153]; and PBD dimers, a DNA damaging agents for cross linking DNA [154].

\section{Conclusions}

It is known that ANXA2 overexpress in the surface of cancer cells and have been announced a biomarker of diagnosis and prognosis of cancers. ANXA2 serve as a potent target of therapeutic intervention and multiple therapeutic strategies targeting ANXA2 have been testified and showed favorable anti-tumor efficacy both in vitro and vivo. Here, we propose a promising targeting peptide with high affinity to ANXA2 selected from phage display technology. Based on the conception of polypeptide which comprised of targeting peptide and pro-apoptotic peptide and ADC which comprised of specific targeting antibody and toxicity compound, we pose a hypothesis that link the targeting peptide to a pro-apoptotic peptide or a mutual toxicity compound. The targeting peptide bind to ANXA2 on tumor cells and trigger the endocytosis, endosomes take the composition into cytoplasm and release the cytotoxic agent from the composition and exert cytotoxicity such as interrupting mitochondria, blocking cell division, damaging DNA.

\section{Acknowledgements}

\section{Funding}

This work was supported by National Natural S cience Foundation of China [No. 82073281, 82073884, 81903658, 81573462, U1608281]; Major Special S\&T Pr ojects in Liaoning Province [2019JH1/10300005]; Liao ning Revitalization Talents Program [No. XLYC18072 01]; Shenyang S\&T Projects [19-109-4-09, 20-204-4-22].

\section{Competing Interests}

The authors have declared that no competing interest exists.

\section{References}

1. Hajjar KA, Krishnan S. Annexin II: a mediator of the plasmin/plasminogen activator system. Trends Cardiovasc Med. 1999; 9: 128-38.

2. Drust DS, Creutz CE. Aggregation of chromaffin granules by calpactin at micromolar levels of calcium. Nature. 1988; 331: 88-91.

3. $\mathrm{Xu} \mathrm{XH,} \mathrm{Pan} \mathrm{W,} \mathrm{Kang} \mathrm{LH,} \mathrm{Feng} \mathrm{H,} \mathrm{Song} \mathrm{YQ.} \mathrm{Association} \mathrm{of} \mathrm{annexin} \mathrm{A2} \mathrm{with}$ cancer development (Review). Oncol Rep. 2015; 33: 2121-8.

4. Wang CY, Lin CF. Annexin A2: its molecular regulation and cellular expression in cancer development. Dis Markers. 2014; 2014: 308976.

5. Hajjar KA, Mauri L, Jacovina AT, Zhong F, Mirza UA, Padovan JC, et al. Tissue plasminogen activator binding to the annexin II tail domain. Direct modulation by homocysteine. J Biol Chem. 1998; 273: 9987-93.

6. Gerke V, Weber K. Identity of p36K phosphorylated upon Rous sarcoma virus transformation with a protein purified from brush borders; calcium-dependent binding to non-erythroid spectrin and F-actin. EMBO J. 1984; 3: 227-33.

7. Gould KL, Woodgett JR, Isacke CM, Hunter T. The protein-tyrosine kinase substrate p36 is also a substrate for protein kinase $\mathrm{C}$ in vitro and in vivo. Mol Cell Biol. 1986; 6: 2738-44.

8. Johnsson N, Marriott G, Weber K. p36, the major cytoplasmic substrate of src tyrosine protein kinase, binds to its p11 regulatory subunit via a short amino-terminal amphiphatic helix. EMBO J. 1988; 7: 2435-42.

9. de Graauw M, Tijdens I, Smeets MB, Hensbergen PJ, Deelder AM, van de Water B. Annexin A2 phosphorylation mediates cell scattering and branching morphogenesis via cofilin Activation. Mol Cell Biol. 2008; 28: 1029-40.

10. Morel E, Gruenberg J. Annexin A2 binding to endosomes and functions in endosomal transport are regulated by tyrosine 23 phosphorylation. J Biol Chem. 2009; 284: 1604-11.

11. Johnstone SA, Hubaishy I, Waisman DM. Phosphorylation of annexin II tetramer by protein kinase $\mathrm{C}$ inhibits aggregation of lipid vesicles by the protein. J Biol Chem. 1992; 267: 25976-81.

12. Deora AB, Kreitzer G, Jacovina AT, Hajjar KA. An annexin 2 phosphorylation switch mediates p11-dependent translocation of annexin 2 to the cell surface. J Biol Chem. 2004; 279: 43411-8.

13. Raynal P, Pollard HB. Annexins: the problem of assessing the biological role for a gene family of multifunctional calcium- and phospholipid-binding proteins. Biochim Biophys Acta. 1994; 1197: 63-93. 
14. Moss SE, Morgan RO. The annexins. Genome Biol. 2004; 5: 219.

15. Lizarbe MA, Barrasa JI, Olmo N, Gavilanes F, Turnay J. Annexin-phospholipid interactions. Functional implications. Int J Mol Sci. 2013; 14: 2652-83.

16. Filipenko NR, Waisman DM. The $\mathrm{C}$ terminus of annexin II mediates binding to F-actin. J Biol Chem. 2001; 276: 5310-5.

17. Kassam G, Manro A, Braat CE, Louie P, Fitzpatrick SL, Waisman DM. Characterization of the heparin binding properties of annexin II tetramer. J Biol Chem. 1997; 272: 15093-100.

18. Hajjar KA, Jacovina AT, Chacko J. An endothelial cell receptor for plasminogen/tissue plasminogen activator. I. Identity with annexin II. J Biol Chem. 1994; 269: 21191-7.

19. Gerke V, Moss SE. Annexins: from structure to function. Physiol Rev. 2002; 82: 331-71.

20. Isacke CM, Trowbridge IS, Hunter T. Modulation of p36 phosphorylation in human cells: studies using anti-p36 monoclonal antibodies. Mol Cell Biol. 1986; 6: 2745-51

21. Rosengarth A, Wintergalen A, Galla HJ, Hinz HJ, Gerke V. Ca2+-independent interaction of annexin I with phospholipid monolayers. FEBS Lett. 1998; 438: 279-84.

22. Madureira PA, Hill R, Miller VA, Giacomantonio C, Lee PW, Waisman DM. Annexin A2 is a novel cellular redox regulatory protein involved in tumorigenesis. Oncotarget. 2011; 2: 1075-93.

23. Kwon M, Yoon CS, Jeong W, Rhee SG, Waisman DM. Annexin A2-S100A10 heterotetramer, a novel substrate of thioredoxin. J Biol Chem. 2005; 280: 23584-92.

24. Ecsedi P, Kiss B, Gogl G, Radnai L, Buday L, Koprivanacz K, et al. Regulation of the Equilibrium between Closed and Open Conformations of Annexin A2 by N-Terminal Phosphorylation and S100A4-Binding. Structure. 2017; 25: 1195-+

25. Morel E, Gruenberg J. The p11/S100A10 Light Chain of Annexin A2 Is Dispensable for Annexin A2 Association to Endosomes and Functions in Endosomal Transport. Plos One. 2007; 2.

26. Kumble KD, Vishwanatha JK. Immunoelectron microscopic analysis of the intracellular distribution of primer recognition proteins, annexin 2 and phosphoglycerate kinase, in normal and transformed cells. J Cell Sci. 1991; 99 ( Pt 4): 751-8.

27. Vishwanatha JK, Jindal HK, Davis RG. The role of primer recognition proteins in DNA replication: association with nuclear matrix in HeLa cells. J Cell Sci. 1992; 101 ( Pt 1): 25-34

28. Boyko V, Mudrak O, Svetlova M, Negishi Y, Ariga H, Tomilin N. A major cellular substrate for protein kinases, annexin II, is a DNA-binding protein. FEBS Lett. 1994; 345: 139-42.

29. Vishwanatha JK, Kumble S. Involvement of annexin II in DNA replication: evidence from cell-free extracts of Xenopus eggs. J Cell Sci. 1993; 105 ( Pt 2): 533-40.

30. Madureira PA, Hill R, Lee PW, Waisman DM. Genotoxic agents promote the nuclear accumulation of annexin A2: role of annexin A2 in mitigating DNA damage. Plos One. 2012; 7: e50591.

31. Fan X, Krahling S, Smith D, Williamson P, Schlegel RA. Macrophage surface expression of annexins I and II in the phagocytosis of apoptotic lymphocytes. Mol Biol Cell. 2004; 15: 2863-72.

32. Sarafian T, Pradel LA, Henry JP, Aunis D, Bader MF. The participation of annexin II (calpactin I) in calcium-evoked exocytosis requires protein kinase C. J Cell Biol. 1991; 114: 1135-47.

33. Emans N, Gorvel JP, Walter C, Gerke V, Kellner R, Griffiths G, et al. Annexin II is a major component of fusogenic endosomal vesicles. J Cell Biol. 1993; 120: 1357-69.

34. Babiychuk EB, Draeger A. Annexins in cell membrane dynamics: $\mathrm{Ca} 2+$-regulated association of lipid microdomains. Journal of Cell Biology. 2000; 150: 1113-23.

35. Mayran N, Parton RG, Gruenberg J. Annexin II regulates multivesicular endosome biogenesis in the degradation pathway of animal cells. EMBO J. 2003; 22: 3242-53.

36. Thiel C, Osborn M, Gerke V. The tight association of the tyrosine kinase substrate annexin II with the submembranous cytoskeleton depends on intact p11- and Ca(2+)-binding sites. J Cell Sci. 1992; 103 ( Pt 3): 733-42.

37. Monastyrskaya K, Babiychuk EB, Hostettler A, Rescher U, Draeger A. Annexins as intracellular calcium sensors. Cell Calcium. 2007; 41: 207-19.

38. Sharma MC, Sharma M. The role of annexin II in angiogenesis and tumor progression: a potential therapeutic target. Curr Pharm Des. 2007; 13: 3568-75.

39. Sharma MC. Annexin A2 (ANX A2): An emerging biomarker and potential therapeutic target for agoressive cancers. Int J Cancer. 2019; 144: 2074-81.

40. Grindheim AK, Saraste J, Vedeler A. Protein phosphorylation and its role in the regulation of Annexin A2 function. Biochim Biophys Acta Gen Subj. 2017; 1861: 2515-29.

41. Chen $\mathrm{CY}$, Lin YS, Chen $\mathrm{CH}$, Chen YJ. Annexin A2-mediated cancer progression and therapeutic resistance in nasopharyngeal carcinoma. J Biomed Sci. 2018; 25: 30.

42. Wang T, Wang Z, Niu R, Wang L. Crucial role of Anxa2 in cancer progression: highlights on its novel regulatory mechanism. Cancer Biol Med. 2019; 16: 671-87.

43. Ma JX, Finley RL, Waisman DM, Sloane BF. Human procathepsin B interacts with the annexin II tetramer on the surface of tumor cells. Journal of Biological Chemistry. 2000; 275: 12806-12.
44. Sharma MR, Rothman V, Tuszynski GP, Sharma MC. Antibody-directed targeting of angiostatin's receptor annexin II inhibits Lewis Lung Carcinoma tumor growth via blocking of plasminogen activation: Possible biochemical mechanism of angiostatin's action. Exp Mol Pathol. 2006; 81: 136-45.

45. Chiang Y, Schneiderman MH, Vishwanatha JK. Annexin II expression is regulated during mammalian cell cycle. Cancer Res. 1993; 53: 6017-21.

46. Folkman J. What is the evidence that tumors are angiogenesis dependent? J Natl Cancer Inst. 1990; 82: 4-6.

47. Moreau K, Ghislat G, Hochfeld W, Renna M, Zavodszky E, Runwal G, et al. Transcriptional regulation of Annexin A2 promotes starvation-induced autophagy. Nat Commun. 2015; 6: 8045.

48. Kazami T, Nie H, Satoh M, Kuga T, Matsushita K, Kawasaki N, et al. Nuclear accumulation of annexin A2 contributes to chromosomal instability by coilin-mediated centromere damage. Oncogene. 2015; 34: 4177-89.

49. Bakhoum SF, Compton DA. Chromosomal instability and cancer: a complex relationship with therapeutic potential. J Clin Invest. 2012; 122: 1138-43.

50. Wang TL, Diaz LA, Romans K, Bardelli A, Saha S, Galizia G, et al. Digital karyotyping identifies thymidylate synthase amplification as a mechanism of resistance to 5-fluorouracil in metastatic colorectal cancer patients. P Natl Acad Sci USA. 2004; 101: 3089-94

51. Chiang Y, Rizzino A, Sibenaller ZA, Wold MS, Vishwanatha JK. Specific down-regulation of annexin II expression in human cells interferes with cell proliferation. Mol Cell Biochem. 1999; 199: 139-47.

52. Zhang HJ, Yao DF, Yao M, Huang H, Wang L, Yan MJ, et al. Annexin A2 silencing inhibits invasion, migration, and tumorigenic potential of hepatoma cells. World J Gastroenterol. 2013; 19: 3792-801.

53. Sarkar S, Swiercz R, Kantara C, Hajjar KA, Singh P. Annexin A2 mediates up-regulation of NF-kappaB, beta-catenin, and stem cell in response to progastrin in mice and HEK-293 cells. Gastroenterology. 2011; 140: 583-95 e4.

54. Martin M, Leffler J, Blom AM. Annexin A2 and A5 Serve as New Ligands for C1q on Apoptotic Cells. Journal of Biological Chemistry. 2012; 287: 33733-44.

55. Nauta AJ, Trouw LA, Daha MR, Tijsma O, Nieuwland R, Schwaeble WJ, et al. Direct binding of $\mathrm{C} 1 \mathrm{q}$ to apoptotic cells and cell blebs induces complement activation. Eur J Immunol. 2002; 32: 1726-36.

56. Levine AJ, Oren $\mathrm{M}$. The first 30 years of p53: growing ever more complex. Nat Rev Cancer. 2009; 9: 749-58.

57. Sharathchandra A, Lal R, Khan D, Das S. Annexin A2 and PSF proteins interact with p53 IRES and regulate translation of p53 mRNA. RNA Biol. 2012; 9: 1429-39.

58. Feng X, Liu H, Zhang Z, Gu Y, Qiu H, He Z. Annexin A2 contributes to cisplatin resistance by activation of JNK-p53 pathway in non-small cell lung cancer cells. J Exp Clin Cancer Res. 2017; 36: 123.

59. Wang CY, Chen CL, Tseng YL, Fang YT, Lin YS, Su WC, et al. Annexin A2 Silencing Induces G(2) Arrest of Non-small Cell Lung Cancer Cells through p53-dependent and -independent Mechanisms. Journal of Biological Chemistry. 2012; 287: 32512-24

60. Huang $Y, Y a n C H, F u$ SB. [The cloning and expression of apoptosis associated gene ANNEXIN A2 induced by p53 gene]. Zhonghua Yi Xue Yi Chuan Xue Za Zhi. 2005; 22: 661-4.

61. Wu MH, Sun YQ, Xu FP, Liang YQ, Liu H, Yi YM. Annexin A2 Silencing Inhibits Proliferation and Epithelial-to-mesenchymal Transition through p53-Dependent Pathway in NSCLCs. J Cancer. 2019; 10: 1077-85.

62. Huang Y, Jin Y, Yan CH, Yu Y, Bai J, Chen F, et al. Involvement of Annexin A2 in p53 induced apoptosis in lung cancer. Mol Cell Biochem. 2008; 309: 117-23.

63. Wang CY, Lin YS, Su WC, Chen CL, Lin CF. Glycogen Synthase Kinase-3 and Omi/HtrA2 Induce Annexin A2 Cleavage followed by Cell Cycle Inhibition and Apoptosis. Molecular Biology of the Cell. 2009; 20: 4153-61.

64. Ding T, Yang LY, Wang YH, Yuan JB, Chen TD, Cai XJ. Down-regulation of annexin II in prostate cancer is associated with Gleason score, recurrence, metastasis and poor prognosis. Mol Med Rep. 2010; 3: 781-7.

65. Wang YX, Lv H, Li ZX, Li C, Wu XY. Effect of shRNA mediated down-regulation of Annexin A2 on biological behavior of human lung adencarcinoma cells A549. Pathol Oncol Res. 2012; 18: 183-90.

66. Wu B, Zhang F, Yu M, Zhao P, Ji W, Zhang H, et al. Up-regulation of Anxa2 gene promotes proliferation and invasion of breast cancer MCF-7 cells. Cell Prolif. 2012; 45: 189-98.

67. Sharma MR, Rothman V, Tuszynski GP, Sharma MC. Antibody-directed targeting of angiostatin's receptor annexin II inhibits Lewis Lung Carcinoma tumor growth via blocking of plasminogen activation: possible biochemical mechanism of angiostatin's action. Exp Mol Pathol. 2006; 81: 136-45.

68. Ling Q, Jacovina AT, Deora A, Febbraio M, Simantov R, Silverstein RL, et al. Annexin II regulates fibrin homeostasis and neoangiogenesis in vivo. J Clin Invest. 2004; 113: 38-48

69. Zhai H, Acharya S, Gravanis I, Mehmood S, Seidman RJ, Shroyer KR, et al. Annexin A2 promotes glioma cell invasion and tumor progression. J Neurosci. 2011; 31: 14346-60.

70. Zheng L, Foley K, Huang LQ, Leubner A, Mo GL, Olino K, et al. Tyrosine 23 Phosphorylation-Dependent Cell-Surface Localization of Annexin A2 Is Required for Invasion and Metastases of Pancreatic Cancer. Plos One. 2011; 6(4).

71. Foley K, Rucki AA, Xiao Q, Zhou D, Leubner A, Mo G, et al. Semaphorin 3D autocrine signaling mediates the metastatic role of annexin A2 in pancreatic cancer. Sci Signal. 2015; 8: ra77. 
72. Liu $\mathrm{Y}, \mathrm{Li} \mathrm{H}$, Ban $\mathrm{Z}$, Nai $\mathrm{M}$, Yang $\mathrm{L}$, Chen $\mathrm{Y}$, et al Annexin A2 inhibition suppresses ovarian cancer progression via regulating beta-catenin/EMT. Oncol Rep. 2017; 37: 3643-50.

73. Agababaoglu I, Onen A, Demir AB, Aktas S, Altun Z, Ersoz H, et al Chaperonin (HSP60) and annexin-2 are candidate biomarkers for non-small cell lung carcinoma. Medicine (Baltimore). 2017; 96: e5903.

74. Deng S, Jing B, Xing T, Hou L, Yang Z. Overexpression of annexin A2 is associated with abnormal ubiquitination in breast cancer. Genomics Proteomics Bioinformatics. 2012; 10: 153-7.

75. Wang YQ, Zhang F, Tian R, Ji W, Zhou Y, Sun XM, et al. Tyrosine 23 Phosphorylation of Annexin A2 Promotes Proliferation, Invasion, and Stat3 Phosphorylation in the Nucleus of Human Breast Cancer SK-BR-3 Cells. Cancer Biol Med. 2012; 9: 248-53.

76. Choi KS, Fitzpatrick SL, Filipenko NR, Fogg DK, Kassam G, Magliocco AM, et al. Regulation of plasmin-dependent fibrin clot lysis by annexin II heterotetramer. J Biol Chem. 2001; 276: 25212-21.

77. Ling Q, Jacovina AT, Deora A, Febbraio M, Simantov R, Silverstein RL, et al. Annexin II regulates fibrin homeostasis and neoangiogenesis in vivo. Journal of Clinical Investigation. 2004; 113: 38-48

78. Andreasen PA, Egelund R, Petersen HH. The plasminogen activation system in tumor growth, invasion, and metastasis. Cell Mol Life Sci. 2000; 57: 25-40.

79. Hayes MJ, Shao D, Bailly M, Moss SE. Regulation of actin dynamics by annexin 2. EMBO J. 2006; 25: 1816-26.

80. Acloque $\mathrm{H}$, Adams MS, Fishwick $\mathrm{K}$, Bronner-Fraser $\mathrm{M}$, Nieto MA. Epithelial-mesenchymal transitions: the importance of changing cell state in development and disease. J Clin Invest. 2009; 119: 1438-49.

81. Thiery JP, Acloque H, Huang RY, Nieto MA. Epithelial-mesenchymal transitions in development and disease. Cell. 2009; 139: 871-90.

82. Chaffer CL, Weinberg RA. A perspective on cancer cell metastasis. Science. 2011; 331: 1559-64.

83. Rocha MR, Barcellos-de-Souza P, Sousa-Squiavinato ACM, Fernandes PV, de Oliveira IM, Boroni M, et al. Annexin A2 overexpression associates with colorectal cancer invasiveness and TGF-ss induced epithelial mesenchymal transition via Src/ANXA2/STAT3. Sci Rep. 2018; 8: 11285.

84. Chen CY, Lin YS, Chen CL, Chao PZ, Chiou JF, Kuo CC, et al. Targeting annexin A2 reduces tumorigenesis and therapeutic resistance of nasopharyngeal carcinoma. Oncotarget. 2015; 6: 26946-59.

85. Sharma MR, Koltowski L, Ownbey RT, Tuszynski GP, Sharma MC. Angiogenesis-associated protein annexin II in breast cancer: Selective expression in invasive breast cancer and contribution to tumor invasion and progression. Exp Mol Pathol. 2006; 81: 146-56.

86. Sharma M, Blackman MR, Sharma MC. Antibody-directed neutralization of annexin II (ANX II) inhibits neoangiogenesis and human breast tumor growth in a xenograft model. Exp Mol Pathol. 2012; 92: 175-84.

87. Shetty PK, Thamake SI, Biswas S, Johansson SL, Vishwanatha JK. Reciprocal regulation of annexin A2 and EGFR with Her-2 in Her-2 negative and herceptin-resistant breast cancer. Plos One. 2012; 7: e44299.

88. Yang T, Peng H, Wang J, Yang J, Nice EC, Xie K, et al. Prognostic and diagnostic significance of annexin A2 in colorectal cancer. Colorectal Dis. 2013; 15: e373-81.

89. Duncan R, Carpenter B, Main LC, Telfer C, Murray GI. Characterisation and protein expression profiling of annexins in colorectal cancer. Br J Cancer. 2008; 98: 426-33.

90. Emoto K, Yamada Y, Sawada H, Fujimoto H, Ueno M, Takayama T, et al. Annexin II overexpression correlates with stromal tenascin-C overexpression: a prognostic marker in colorectal carcinoma. Cancer. 2001; 92: 1419-26.

91. Zhang Q, Ye ZY, Yang Q, He XJ, Wang HJ, Zhao ZS. Upregulated expression of Annexin II is a prognostic marker for patients with gastric cancer. World J Surg Oncol. 2012; 10.

92. Mohammad HS, Kurokohchi K, Yoneyama H, Tokuda M, Morishita A, Jian G, et al. Annexin A2 expression and phosphorylation are up-regulated in hepatocellular carcinoma. Int J Oncol. 2008; 33: 1157-63.

93. Brichory FM, Misek DE, Yim AM, Krause MC, Giordano TJ, Beer DG, et al. An immune response manifested by the common occurrence of annexins I and II autoantibodies and high circulating levels of IL-6 in lung cancer. Proc Natl Acad Sci U S A. 2001; 98: 9824-9.

94. Yao HX, Zhang ZQ, Xiao ZQ, Chen YH, Li C, Zhang PF, et al. Identification of metastasis associated proteins in human lung squamous carcinoma using two-dimensional difference gel electrophoresis and laser capture microdissection. Lung Cancer. 2009; 65: 41-8.

95. Menell JS, Cesarman GM, Jacovina AT, McLaughlin MA, Lev EA, Hajjar KA. Annexin II and bleeding in acute promyelocytic leukemia. N Engl J Med. 1999; 340: 994-1004.

96. Liu Y, Wang Z, Jiang M, Dai L, Zhang W, Wu D, et al. The expression of annexin II and its role in the fibrinolytic activity in acute promyelocytic leukemia. Leuk Res. 2011:35: 879-84.

97. Niu Y, Yang X, Chen Y, Jin X, Xie Y, Tang Y, et al. Distinct prognostic values of Annexin family members expression in acute myeloid leukemia. Clin Transl Oncol. 2019; 21: 1186-96.

98. Roseman BJ, Bollen A, Hsu J, Lamborn K, Israel MA. Annexin II marks astrocytic brain tumors of high histologic grade. Oncol Res. 1994; 6: 561-7.

99. Bao H, Jiang M, Zhu M, Sheng F, Ruan J, Ruan C. Overexpression of Annexin II affects the proliferation, apoptosis, invasion and production of proangiogenic factors in multiple myeloma. Int J Hematol. 2009; 90: 177-85.
100. Esposito I, Penzel R, Chaib-Harrireche M, Barcena U, Bergmann F, Riedl S, et al. Tenascin $C$ and annexin II expression in the process of pancreatic carcinogenesis. J Pathol. 2006; 208: 673-85.

101. Vishwanatha JK, Chiang Y, Kumble KD, Hollingsworth MA, Pour PM. Enhanced expression of annexin II in human pancreatic carcinoma cells and primary pancreatic cancers. Carcinogenesis. 1993; 14: 2575-9.

102. Takano S, Togawa A, Yoshitomi H, Shida T, Kimura F, Shimizu H, et al. Annexin II overexpression predicts rapid recurrence after surgery in pancreatic cancer patients undergoing gemcitabine-adjuvant chemotherapy. Ann Surg Oncol. 2008; 15: 3157-68.

103. Rodrigo JP, Lequerica-Fernandez P, Rosado P, Allonca E, Garcia-Pedrero JM, de Vicente JC. Clinical significance of annexin A2 downregulation in oral squamous cell carcinoma. Head Neck. 2011; 33: 1708-14.

104. Zhong LP, Wei KJ, Yang X, Zhang L, Zhou XJ, Pan HY, et al. Increased expression of Annexin A2 in oral squamous cell carcinoma. Arch Oral Biol. 2009; 54: 17-25.

105. Zhang H, Yao M, Wu W, Qiu L, Sai W, Yang J, et al. Up-regulation of annexin A2 expression predicates advanced clinicopathological features and poor prognosis in hepatocellular carcinoma. Tumour Biol. 2015; 36: 9373-83.

106. Lokman NA, Pyragius CE, Ruszkiewicz A, Oehler MK, Ricciardelli C. Annexin A2 and S100A10 are independent predictors of serous ovarian cancer outcome. Transl Res. 2016; 171: 83-95 e1-2.

107. Deng Y, Chen C, Hua M, Xi Q, Liu R, Yang S, et al. Annexin A2 plays a critical role in epithelial ovarian cancer. Arch Gynecol Obstet. 2015; 292: 175-82.

108. Zhang Q, Zhao ZS, Ma YY, Wang HJ, Ma J, He XJ, et al. Combined expression of S100A4 and Annexin A2 predicts disease progression and overall survival in patients with urothelial carcinoma. Urol Oncol-Semin Ori. 2014; 32: 798-805.

109. Wang T, Yuan J, Zhang J, Tian R, Ji W, Zhou Y, et al. Anxa2 binds to STAT3 and promotes epithelial to mesenchymal transition in breast cancer cells. Oncotarget. 2015; 6: 30975-92.

110. Chuthapisith S, Bean BE, Cowley G, Eremin JM, Samphao S, Layfield R, et al. Annexins in human breast cancer: Possible predictors of pathological response to neoadjuvant chemotherapy. Eur J Cancer. 2009; 45: 1274-81.

111. Liu X, Ma D, Jing X, Wang B, Yang W, Qiu W. Overexpression of ANXA2 predicts adverse outcomes of patients with malignant tumors: a systematic review and meta-analysis. Med Oncol. 2015; 32: 392.

112. El-Abd N, Fawzy A, Elbaz T, Hamdy S. Evaluation of annexin A2 and as potential biomarkers for hepatocellular carcinoma. Tumor Biol. 2016; 37: 211-6.

113. Sun YL, Gao GZ, Cai JQ, Wang YL, Qu XH, He LD, et al. Annexin A2 is a discriminative serological candidate in early hepatocellular carcinoma. Carcinogenesis. 2013; 34: 595-604.

114. Shaker MK, Abdel Fattah HI, Sabbour GS, Montasser IF, Abdelhakam SM, El Hadidy E, et al. Annexin A2 as a biomarker for hepatocellular carcinoma in Egyptian patients. World J Hepatol. 2017; 9: 469-76.

115. Tas F, Yasasever CT, Karabulut S, Tastekin D, Duranyildiz D. Circulating annexin A2 as a biomarker in gastric cancer patients: Correlation with clinical variables. Biomed Pharmacother. 2015; 69: 237-41.

116. Zhang W, Gao $\mathrm{CH}$, Zhang SH, Fang GQ. Serum Annexin A2 Level Is Associated With Diagnosis and Prognosis in Patients With Oral Squamous Cell Carcinoma. J Oral Maxil Surg. 2017; 75: 1081-7.

117. Alonso-Alconada L, Santacana M, Garcia-Sanz P, Muinelo-Romay L, Colas E, Mirantes C, et al. Annexin-A2 as predictor biomarker of recurrent disease in endometrial cancer. Int J Cancer. 2015; 136: 1863-73.

118. Cheng K, Lee JS, Hao P, Yao SQ, Ding K, Li Z. Tetrazole-Based Probes for Integrated Phenotypic Screening, Affinity-Based Proteome Profiling, and Sensitive Detection of a Cancer Biomarker. Angew Chem Int Ed Engl. 2017; 56: 15044-8

119. Shetty PK, Thamake SI, Biswas S, Johansson SL, Vishwanatha JK. Reciprocal Regulation of Annexin A2 and EGFR with Her-2 in Her-2 Negative and Herceptin-Resistant Breast Cancer (vol 7, e44299, 2012). Plos One. 2012; 7.

120. Bao J, Xu Y, Wang Q, Zhang J, Li Z, Li D, et al. miR-101 alleviates chemoresistance of gastric cancer cells by targeting ANXA2. Biomed Pharmacother. 2017; 92: 1030-7.

121. Wang K, Zhang T, Lei YL, Li XF, Jiang JW, Lan J, et al. Identification of ANXA2 (annexin A2) as a specific bleomycin target to induce pulmonary fibrosis by impeding TFEB-mediated autophagic flux. Autophagy. 2018; 14: 269-82.

122. Wang YS, Li H, Li Y, Zhu H, Jin YH. Identification of natural compounds targeting Annexin A2 with an anti-cancer effect. Protein Cell. 2018; 9: 568-79.

123. Shetty P, Bargale A, Patil BR, Mohan R, Dinesh US, Vishwanatha JK, et al. Cell surface interaction of annexin A2 and galectin-3 modulates epidermal growth factor receptor signaling in Her-2 negative breast cancer cells. Mol Cell Biochem. 2016; 411: 221-33.

124. Wang DY, Cao Y, Zheng LY, Lv DY, Chen LD, Xing XR, et al. Identification of Annexin A2 as a target protein for plant alkaloid matrine. Chem Commun. 2017; 53: 5020-3

125. Pi FM, Zhang H, Li H, Thiviyanathan V, Gorenstein DG, Sood AK, et al. RNA nanoparticles harboring annexin A2 aptamer can target ovarian cancer for tumor-specific doxorubicin delivery. Nanomed-Nanotechnol. 2017; 13: 1183-93.

126. Doerflinger A, Quang NN, Gravel E, Duconge F, Doris E. Aptamer-decorated polydiacetylene micelles with improved targeting of cancer cells. Int J Pharm. 2019; 565: 59-63.

127. Andey T, Marepally S, Patel A, Jackson T, Sarkar S, O'Connell M, et al. Cationic lipid guided short-hairpin RNA interference of annexin A2 attenuates 
tumor growth and metastasis in a mouse lung cancer stem cell model. J Control Release. 2014; 184: 67-78.

128. Keklikoglou I, Hosaka K, Bender C, Bott A, Koerner C, Mitra D, et al. MicroRNA-206 functions as a pleiotropic modulator of cell proliferation, invasion and lymphangiogenesis in pancreatic adenocarcinoma by targeting ANXA2 and KRAS genes. Oncogene. 2015; 34: 4867-78.

129. Xiao $\mathrm{L}$, Jin $\mathrm{H}$, Duan $\mathrm{W}$, Hou $\mathrm{Y}$. Roles of N-terminal Annexin A2 phosphorylation sites and miR-206 in colonic adenocarcinoma. Life Sci. 2020; 253: 117740

130. Kim VM, Blair AB, Lauer P, Foley K, Che X, Soares K, et al. Anti-pancreatic tumor efficacy of a Listeria-based, Annexin A2-targeting immunotherapy in combination with anti-PD-1 antibodies. J Immunother Cancer. 2019; 7: 132.

131. Sharma MC, Tuszynski GP, Blackman MR, Sharma M. Long-term efficacy and downstream mechanism of anti-annexinA2 monoclonal antibody (anti-ANX $\mathrm{A} 2 \mathrm{mAb}$ ) in a pre-clinical model of aggressive human breast cancer. Cancer Lett. 2016; 373: 27-35.

132. Cua S, Tan HL, Fong WJ, Chin A, Lau A, Ding V, et al. Targeting of embryonic annexin A2 expressed on ovarian and breast cancer by the novel monoclonal antibody 2448. Oncotarget. 2018; 9: 13206-21.

133. Tan HL, Tan BZ, Goh WXT, Cua S, Choo A. In vivo surveillance and elimination of teratoma-forming human embryonic stem cells with monoclonal antibody 2448 targeting annexin A2. Biotechnol Bioeng. 2019; 116: 2996-3005.

134. Staquicini DI, Rangel R, Guzman-Rojas L, Staquicini FI, Dobroff AS, Tarleton $\mathrm{CA}$, et al. Intracellular targeting of annexin A2 inhibits tumor cell adhesion, migration, and in vivo grafting. Sci Rep. 2017; 7: 4243.

135. Ellerby HM, Arap W, Ellerby LM, Kain R, Andrusiak R, Rio GD, et al. Anti-cancer activity of targeted pro-apoptotic peptides. Nat Med. 1999; 5: $1032-8$.

136. Sun JW, Jiang L, Lin Y, Gerhard EM, Jiang XH, Li L, et al. Enhanced anticancer efficacy of paclitaxel through multistage tumor-targeting liposomes modified with RGD and KLA peptides. Int J Nanomed. 2017; 12: 1517-37.

137. Huang Y, Li X, Sha H, Zhang L, Bian X, Han X, et al. Tumor-penetrating peptide fused to a pro-apoptotic peptide facilitates effective gastric cancer therapy. Oncol Rep. 2017; 37: 2063-70.

138. Thornberry NA, Rosen A, Nicholson DW. Control of apoptosis by proteases. Adv Pharmacol. 1997; 41: 155-77.

139. Van De Water TR, Lallemend F, Eshraghi AA, Ahsan S, He J, Guzman J, et al. Caspases, the enemy within, and their role in oxidative stress-induced apoptosis of inner ear sensory cells. Otol Neurotol. 2004; 25: 627-32.

140. Chu DS, Bocek MJ, Shi J, Ta A, Ngambenjawong C, Rostomily RC, et al. Multivalent display of pendant pro-apoptotic peptides increases cytotoxic activity. J Control Release. 2015; 205: 155-61.

141. Foillard S, Jin ZH, Garanger E, Boturyn D, Favrot MC, Coll JL, et al. Synthesis and biological characterisation of targeted pro-apoptotic peptide. Chembiochem. 2008; 9: 2326-32

142. Marks AJ, Cooper MS, Anderson RJ, Orchard KH, Hale G, North JM, et al. Selective apoptotic killing of malignant hemopoietic cells by antibody-targeted delivery of an amphipathic peptide. Cancer Res. 2005; 65: 2373-7.

143. Hyun S, Lee S, Kim S, Jang S, Yu J, Lee Y. Apoptosis inducing, conformationally constrained, dimeric peptide analogs of KLA with submicromolar cell penetrating abilities. Biomacromolecules. 2014; 15: 3746-52.

144. Javadpour MM, Juban MM, Lo WC, Bishop SM, Alberty JB, Cowell SM, et al. De novo antimicrobial peptides with low mammalian cell toxicity. J Med Chem. 1996; 39: 3107-13.

145. Lambert JM, Berkenblit A. Antibody-Drug Conjugates for Cancer Treatment. Annu Rev Med. 2018; 69: 191-207.

146. Nejadmoghaddam MR, Minai-Tehrani A, Ghahremanzadeh R, Mahmoudi M, Dinarvand R, Zarnani AH. Antibody-Drug Conjugates: Possibilities and Challenges. Avicenna J Med Biotechnol. 2019; 11: 3-23.

147. Khongorzul P, Ling CJ, Khan FU, Ihsan AU, Zhang J. Antibody-Drug Conjugates: A Comprehensive Review. Mol Cancer Res. 2020; 18: 3-19.

148. Yu B, Liu D. Antibody-drug conjugates in clinical trials for lymphoid malignancies and multiple myeloma. J Hematol Oncol. 2019; 12: 94.

149. Doronina SO, Toki BE, Torgov MY, Mendelsohn BA, Cerveny CG, Chace DF, et al. Development of potent monoclonal antibody auristatin conjugates for cancer therapy. Nat Biotechnol. 2003; 21: 778-84.

150. Widdison WC, Wilhelm SD, Cavanagh EE, Whiteman KR, Leece BA, Kovtun $\mathrm{Y}$, et al. Semisynthetic maytansine analogues for the targeted treatment of cancer. J Med Chem. 2006; 49: 4392-408.

151. Smith AL, Nicolaou KC. The enediyne antibiotics. J Med Chem. 1996; 39: 2103-17.

152. Elgersma RC, Coumans RG, Huijbregts T, Menge WM, Joosten JA, Spijker HJ, et al. Design, Synthesis, and Evaluation of Linker-Duocarmycin Payloads: Toward Selection of HER2-Targeting Antibody-Drug Conjugate SYD985. Mol Pharm. 2015; 12: 1813-35.

153. Miller ML, Fishkin NE, Li W, Whiteman KR, Kovtun Y, Reid EE, et al. A New Class of Antibody-Drug Conjugates with Potent DNA Alkylating Activity. Mol Cancer Ther. 2016; 15: 1870-8.

154. Sutherland MSK, Walter RB, Jeffrey SC, Burke PJ, Yu CP, Kostner H, et al. SGN-CD33A: a novel CD33-targeting antibody-drug conjugate using a pyrrolobenzodiazepine dimer is active in models of drug-resistant AML. Blood. 2013; 122: 1455-63. 